\title{
"A Tale of Two Croatias": How Club Football (Soccer) Teams Produce Radical Regional Divides in Croatia's National Identity
}

\author{
Dustin Y. Tsai ${ }^{\star}$ (D) \\ Geography Graduate Group, University of California, Davis, California, USA \\ *Corresponding author. Email: dytsai@ucdavis.edu
}

\begin{abstract}
Croatia's monumental second-place finish at the 2018 FIFA World Cup represents the highest football achievement to date for the young nation. This victory, however, masks violent internal divisions between its domestic club football teams. This article examines the most salient rivalry between Dinamo Zagreb and Hajduk Split, two teams that have evolved to represent the interests of Croatia's north and south, respectively. Using interviews with radical football fans, I argue that the two teams act as reservoirs for regional identity-building while violence between their fans is a microcosm for political and economic tensions between Zagreb and Split. More importantly, this rivalry exposes the dividedness of the Croatian state, as it continues to grapple with the complexity of its radical regional identities in the wake of its independence from Yugoslavia. This article contributes to the existing body of literature on sports identity and regionalisms/nationalism as well as how sporting teams shape the geographies of belonging.
\end{abstract}

Keywords: sports; soccer; regionalism; nationalism; football

\section{Introduction}

On October 21, 2017, I found myself in Split, Croatia, buying a last-minute ticket to one of the soccer season's most highly anticipated games: Hajduk, the local club football team based in Split, was set to take on their notorious rivals, Dinamo, the visiting team based in Zagreb, representing what is perhaps the fiercest sporting rivalry within the nation. "Make sure you don't wear blue today," a local friend advised me that morning. "People will mistake you for a Dinamo fan and you do not want that," he sternly warned. The streets of Split were colorfully adorned in red and white, as passers-by came and went dressed in the colors of the local football team. Game day it was, and a stiff feeling of anticipation filled the air of the old town.

I passed a street-side vendor selling game-day gear and decided to pick out a red and white Hajduk scarf, as I jostled my way to the game amidst the crowd of eager spectators. Outside Poljud Stadium, thousands of football fans congregated, happily tossing back a beer or two before making their way inside. Alcohol was expressly banned inside the venues, one of myriad changes implemented in recent years as part of efforts to mitigate the violence that often accompanied these games. My scarf bore colors friendly to the home team, and local fans flashed smiles of approval at me as I entered the stadium. I could not help but to wonder how they would have reacted had I worn the wrong colors that day.

Inside, the stadium was a sea blanketed in white. Along the top was a series of years listing the seasons in which Hajduk had won the Croatian First League-2005 being the most recent year. Their visiting rival, in contrast, had won a staggering twelve of the last thirteen seasons. "That's the beauty

(C) Association for the Study of Nationalities 2020. This is an Open Access article, distributed under the terms of the Creative Commons Attribution licence (http://creativecommons.org/licenses/by/4.0/), which permits unrestricted re-use, distribution, and reproduction in any medium, provided the original work is properly cited. 
of Hajduk fans," a young woman exclaimed to me. "Love us or hate us-we are the most loyal and fill all the games, win or lose." At the north end, a teenager proudly swung a gargantuan Hajduk flag which towered above the crowd. At the opposite end, the stands reserved for the visiting team remained empty. "I think no more than two-hundred of them will show up," the man next to me claimed, pointing to the empty bleachers in the away section. "They have to bus those fans in because they need their police protection," he wryly remarked with a grin. A few minutes remained before kick-off, and I could smell the excitement in the arena.

As the first Dinamo player took the field, the stadium erupted into a cacophony of boos and jeers, as taunting chants bellowed throughout the stadium. In a matter of minutes, the home team quickly scored, as the massive crowds roared behind them. Flares and firecrackers immediately lit up in response, as young fans hurled smoke bombs onto the field. By the end of the first half, the game had taken a disruption pause; firefighters rushed to extinguish flames as white smoke began to fill the arena.

Throughout the second half, the red-and-white Hajduk squad continued to hold their own, leading their blue-adorned counterparts into the 89th minute. Dinamo fought back, scoring backto-back goals during stoppage time, as the crowd recoiled in anguish. In the final minutes, the home team was awarded one last penalty kick. A veteran striker took the pitch, hesitating slightly, before narrowly landing an equalizing goal. The game had ended in a tie, 2-2, and the spectators thunderously cheered. On the outside, this game represented a hotly contested rivalry between the two most dominant teams of Croatia. To the radical fans of Dinamo and Hajduk, this "derby" symbolized something much greater than just a sporting match.

\section{Background}

Sports contacts are important geopolitical rituals that have the capacity to both bridge and divide disparate groups of people. On an international scale, these contacts often serve as diplomatic opportunities for international reconciliation between states, particularly as a medium for defusing conflicts (Murray and Pigman 2014; L'Etang 2013; Rowe 2011). The "ping-pong diplomacy" between the United States and Communist China during the Nixon era represents an example of this type of facilitative use (Kobierecki 2017a). More recently, the 2018 Winter Olympics presented an opportunity for North and South Korea to reignite diplomatic relations through their symbolic decision to compete under the same flag (Snyder 2018). In the absence of tensions, these contacts enhance existing relations between states, such as cricket's continued importance as an intercultural link between British Commonwealth states, fostering frequent interactions between states as geographically distant as Fiji and South Africa (Devan 2012; Allen 2009). Sporting bodies serve as important mediators for these linkages, with the International Cricket Council, for instance, having fostered interactions between India and Pakistan in spite of the cooled relations between the two states since their partitioning. On a broader scale, the global popularity of football produces a net benefit to geopolitical exchange between "football nations" and fosters an intercultural affinity between Latin American, West African, and European states. The FIFA World Cup remains the most-watched sporting event in the world, with over half of all people having tuned in to the 2018 final between France and Croatia (FIFA 2018).

Not all sporting engagements, however, act as cohesive sociological tools for rapprochement. Sports contacts can also engender the opposite effect by reproducing divisions between existing social groups. Internationally, this can create unfavorable diplomatic outcomes with state-led boycotts or the barring of others from participation being ways in which these contacts can be negatively weaponized (Murray 2012; Saxena 2011; Cashmore 2000). The United States-led boycott of the 1980 Olympic games in Moscow in protest of the Soviet invasion of Afghanistan represents one such use of this type of hostile diplomacy. Clashes between fans of Honduras and El Salvador in a controversial qualifier for the 1970 FIFA World Cup represents another unfavorable outcome, as its escalation inadvertently led to an all-out war between the two nations (Murray and Pigman 2014; Jackson and Haigh 2008). The hostage crisis at the 1972 Munich Olympics ultimately strained 
geopolitical tensions between regional players in the Israeli-Palestinian conflict. Sporting encounters at the international level remain important geopolitical rituals that have the capacity to either enhance existing relations between states or create avenues for confrontation that can be highly consequential. As J. A. Mangan argued about the making of modern European nations, sports have acted both "internally as an agent of consolidation stressing similarity" as well as "externally as an agent of confrontation emphasizing difference” (1996).

\section{Sport as a Nation's Identity}

The existing literature linking sports and identity have largely utilized the nation-state as the primary scale of analysis (inter alia Casaqui 2015; Hong 2011; Sindbaek 2013). A sport can easily be nationalized to represent the "international brand" of a country and has the potential to influence the global image toward a state's collective people (Kobierecki 2017b). Having success in international competitions is a factor in global indexes of "soft power" and certainly plays a role in influencing how states are perceived on the global stage (Nye 2009; Abdi et al. 2018). Various works have demonstrated a variety of connections between state-level teams and their impact on nationbuilding projects and national identity.

Eunah Hong's (2011) work on the South Korean government's nationalizing of elite sports in recent decades points to the salient role government policies have played in developing Korea's international image as a "modern" Asian nation (Won and Hong 2015; Mangan et al. 2013). Beginning with the 1988 Olympics in Seoul, the government invested heavily in sports-related infrastructure as a means of attracting positive international coverage of its political stability (Hong 2011). South Korea's sports policy shifts have created several celebrity athletes who serve as de facto cultural ambassadors for the Korean national brand, such as Kim Yuna, who has interwoven figure skating into the cultural fabric of the nation (Tosa 2015; Seib 2009). Vander Casaqui's (2015) work on Brazil's nationalization of football, on the other hand, depicts the organic manner in which the sport gained traction as a popular pastime in the late 19th century, before rapidly transforming the country into what locals affectionately call today $O$ pais de Futebol (the country of football). The unmistakable yellow and green colors of Brazil's national team have come to embody the nation's international brand, propelled by its historical success as the most-decorated FIFA World Cup team. Pele has ascended to becoming a cultural icon, with his rise from a favela to superstar status, symbolizing the economic dream for millions of Brazilians living in poverty (Casaqui 2015). Football remains a mostly unifying force for the Brazilian national identity-one that has been plagued by a turbulent legacy of racial and ethnic divisions in its past.

In the case of Yugoslavia, Marshal Tito's socialist state arose as a territorial project aimed at unifying the South Slav nations, despite their heterogenous religious divisions. His policies involved a conscious engineering of football and basketball as national sports, deliberately using the accomplishments of the national team as a means for integrating Yugoslavia's internally diverse populations (Mills 2018; Perica 2001). While the "Croatian Spring" demonstrations of 1968-1971 and the 1981 riots in Kosovo exemplified periodic waves of internal splintering, Tito's suppression of nationalism during the socialist period remained mostly effective, as demonstrated by the high rate of intermarriage between religious groups prior to the conflicts of the 1990s (Smits 2010). For decades, the national team served as an instrumental reservoir for which Yugoslav national identity was built upon, and since the dissolution of Yugoslavia, successor states have sought to forge national identities around sports in the same way. This dynamic of using sporting successes as a reservoir for nationalism continues to be replicated, now operating within the confines of each successor state (Brentin 2016).

One important theme within the post-Yugoslav sports literature is the examination of how football teams (re)produce the national identities of each successor state. These works have documented local processes in Montenegro (Popovic and Bjelica 2014) and Slovenia (Topić and Coakley 2010) among other regional case studies and acknowledge Yugoslavia's historical blueprint 
of creating sporting institutions conducive to nation-building in the Balkans. Most visibly apparent is the ongoing prevalence of nationalist symbols at sporting matches, with the presence of divisive slogans and songs at games reproducing national imaginings among the fans who chant them (Sindbaek 2013). International matches have become a proxy for Balkan geopolitical contacts, as controversies in volleyball, handball, and football continue to plague international sporting in the region (Mills 2009). In one instance, a 2014 European football championship qualifying match between Serbia and Albania saw significant disruption after a drone was flown onto the pitch, carrying a banner displaying Kosovo as a part of Greater Albania. This provoked a swarm of fighting between players and fans, erupting into a chaotic brawl on the field that eventually led to the cancellation of the game (Baker 2016). Struggles to define the nation continuously unfold through sports in the Balkans, as international matches continue to symbolize the ongoing geopolitical disputes that persist between these states (Hughson and Skillen 2014).

\section{Sporting Culture in Croatia}

Within Croatia, the literature has explored multiple aspects of football culture, including modernday violence (i.e., "hooliganism") and resistance in the arena (Lalić and Wood 2014; Perasović and Mustapić 2013), the use of historical imagery and symbols for nation-building (Hrstić and Mustapić 2015; Pavlaković 2014), and sporting rituals as a transmitter of social knowledge and values (Brentin 2014, 2016; Hay 1998). As famously remarked by Croatia’s first president and leader during the disintegration of Yugoslavia, "football victories shape a nation's identity as much as wars do" (Brentin 2013), and the sport, no doubt, has established itself as a highly politicized form of national expression in the state today (Brentin 2016). Most popular among the youth, it represents an important pastime, carrying with it strong cultural and political connotations. Yet most of Croatia's everyday football fanaticism does not operate at the national level. Having been independent for only two decades, Croatia's national team has had little time to develop a truly radical following; rather, the bulk of its nationalist sentiments in sporting are expressed sub-nationally, with radical regional followings organized around local club football teams. This is like the dynamics of post-colonial India, in which local football teams sustained tense regional rivalries that undermined the significance of the national team during its early years of independence (Majumdar and Bandyopadhyay 2005). In Croatia, however, these teams have been around since the early twentieth century and have long embedded themselves into the cultural fabric of the cities and regions they represent. Their persistence in a landscape that has seen multiple territorial changes in the last century demonstrates the intractable character of these regionalisms.

At the sub-national level, Dinamo Zagreb and Hajduk Split's notorious rivalry represents a division in the nation that has exploded in the last two decades. Following the independence of Croatia, these two teams have grown to symbolize two main regional identities that exist largely in opposition to one another: A Zagreb-based, pan-Croat identity and a Split-based coastal identity in the nation's south. Both teams draw their support from fans within their geographical spheres of influence. Dinamo has expanded to representing not just Zagreb but its surrounding regions, with its cultural influence extending across northern Croatia. In contrast, Hajduk has grown from its roots in Split to embodying the coastal region of Dalmatia as a whole, encompassing Croatia's southern Adriatic coast as well as parts of southern Bosnia-Herzegovina. While smaller club teams also have their own reflective fanbases (e.g., HNK Rijeka), most Croatian football's radicalism today mirrors the north-south division created by Dinamo and Hajduk. As highly powerful organizations, these two teams currently wield greater influence than many political parties and trade unions within the state (Perasović and Mustapić 2013). Their supporters have influenced elections, made changes to the legal system, and successfully lobbied for various initiatives, such as the democratization of sporting institutions (Tregoures 2017). They represent cultural, political, and economic expressions of the two dominant regionalisms within Croatia and challenge the cohesiveness of Croatia's national identity. 
The literature on these two teams first began with the contributions of a few works from the late Yugoslavian period. Namely, Fanuko and Nadin's (1991) portrait of the radical supporters of Dinamo Zagreb and Lalic's (1993) documentation of Hajduk Split. Benjamin Perasovic's (1995) work then documented violence in the club football world during Croatia's transition out of Yugoslavia, while Bellamy (2003) provided a much-needed overview of Dinamo Zagreb's complex dynamic with Tudjman and the state during the 1990s. Most of the literature concerning these teams dropped off in the 2000s, though the recent revival of works since 2013 have focused solely on how the teams reproduce national identity and make no mention of contemporary regionalisms. Very little research exists documenting the current impact Croatia's two dominant club football teams have on both regional and national identity-building in a post-Yugoslav context. This is a crucial temporal distinction considering the sociopolitical and economic changes Croatia has experienced since its 2013 ascension into the European Union, a move that has triggered massive youth emigration among other social upheavals. Dario Brentin's recent works $(2013,2014,2016)$ on football in post-socialist Croatia have brought to light the sport's ritual and symbolic value for the nation. Though like most other contemporary works on Croatia, it overlooks the sub-national and regional identities within the nation that are buttressed by the persistence of club football teams. Similarly, Perasović and Mustapić (2018) and Tregoures (2017) both detail hooliganism subcultures within Hajduk quite effectively, but neither makes any mention of their findings within a Dalmatian regionalist context. The nexus between club football organizations and Croatia's regional identities remains a largely unexplored gap within the literature on sports and identitymaking. This scale of analysis is particularly important for geographers who seek to understand patterns outside of the traditional nation-state paradigm (inter alia Agnew 1998). The electoral rise of the right-leaning Croatian Democratic Union (HDZ) in recent years has largely been associated with a surge in Croat nationalism, yet the burgeoning regionalisms within the sporting world seem to challenge the HDZ's ideals of a monolithic national identity. By examining the culture of the two dominant club football teams in Croatia, this article explores the impacts football fanaticism has had on (re)producing regionalisms and how these regionalisms ideologically undermine the notion of a unified Croatian nation as purported by nationalists, bringing to light the complexity behind Croatia's national identity.

\section{Methodology}

This article explores the nuances behind how club football teams have reshaped ideas of national and regional identity in Croatia. The data presented in this work is gathered from a larger research project undertaken on contemporary youth nationalism in the Balkans. Nationalist and regionalist sentiments are not easy topics to break ground on qualitatively, as fear of judgement or social backlash can discourage many from divulging their true beliefs. I therefore utilized a three-pronged approach to my recruitment of informants. First, I contacted and affiliated with faculty from the University of Rijeka and the University of Zagreb as a jumping-off point for connecting with key local and regional figures in Croatia. My second method involved snowball sampling within the networks of local contacts I made from a pilot trip I undertook in 2014. Third, I opened my recruitment of informants to impromptu encounters with local youth by attending football matches and public events. This multi-faceted approach allowed me to speak with a variety of participants that included key regional informants as well as everyday people without privileging one group over another. My fieldwork led me across dozens of towns and villages where I encountered over a hundred Croats of different socio-political backgrounds. I visited local coaches, spoke with many young football fans, and even had the opportunity to interview a member of the Sabor-Croatia's legislative parliament. These interviews took place both inside matches and outside the environment of sports and were structured as extended conversations in order to elicit more authentic data on the underlying beliefs each informant held. Understanding the nuances of how regional identities are constructed often involves sensitive topics such as how individual informants 
articulate their own prejudices toward outgroups. Therefore, the relaxed nature in which I conducted these interviews allowed me to inductively uncover deeply rooted beliefs that a more rigidly structured protocol would have notably stymied. The ultimate frankness with which my informants spoke to me reflects the great deal of effort I made to establish trust and build rapport with individuals. Due to the sensitive nature of these topics, the names of all those I interviewed are withheld by mutual agreement. My interviews ranged from 20-minute discussions with everyday spectators to full-day engagements with radically self-professed "hooligans," many of whom chose to confidentially speak at length with me regarding their active engagements with violence, as well as criminal affiliations, at these events. It is a humbling endeavor to be able to present this data, which I believe paints a raw picture of some of the effects club football culture has had on reifying Croatian regionalisms in the decades since the collapse of Yugoslavia.

\section{Dinamo Zagreb}

As one of the four titans of Yugoslavian football, Dinamo Zagreb is the most successful team in Croatian football history, having won 20 of the 28 Croatian Football League titles since the foundation of the domestic First League in 1992. The club team saw similar success under Yugoslavia, having won seven national titles before the state's breakup. Dinamo fans adorn themselves in a royal blue accoutrement on game days, reflecting the colors of the team and their aptly named fanbase, the "Bad Blue Boys." The characteristic "BBB" graffiti is highly visible throughout Zagreb, and building walls are often tagged with the familiar blue mark. Dinamo's political reach extends well beyond the realm of sports, playing a pivotal role in shaping the cultural fabric of northern Croatia. In a central Zagreb pub, I interviewed a master's student who described to me the inception of his fervor toward Dinamo, which came at an early age:

Dinamo recruited us when we were young kids in primary school. They gave us footballs and shirts and, as a kid, it makes you feel so cool to be wearing that stuff... to be a part of something like that, it's so great. It's hard for me to explain to you what that feeling is like, but for us it's not about the game, it's about the feeling of belonging to something like that... it is about the culture it gave us. (Interview with a 21-year-old, male Dinamo fan in Zagreb, September 2017)

This fan's own early fascination with owning football merchandise created an opportunity for him to find an affiliation with Dinamo at a very young age. As he states, his own captivation with the team came from an early exposure to the club through gear distributed to him as a child. These methods, though ostensibly innocuous, are influential in socializing young children to subscribe to certain cultural ideals at an early age. Football clubs utilize these highly impressionable interactions with kids, fostering a linkage that allows them to develop a deeper psychological affinity with the team itself. These strategies are well documented in fostering higher levels of sport attendance and consumption (Wann, Ensor, and Bilyeu 2001; Melnick and Wann 2004). By exposing youth to the "culture" of the team at an early age, they become connected to a political collective that becomes a part of their social identity as they age. I spoke with another youth who expanded further on his own connection as a fan to the team and the geographical limitations he faces as a result of that affinity:

I have always been a Dinamo fan since I was a kid, maybe five, six-years-old... to cheer for my team and enjoy the atmosphere of the sport makes me feel I belong. I am a huge fan. But to be a Dinamo fan [in Dalmatia] is very dangerous... there are people that are prejudiced. If I go to Split, there are a lot of crazy people that will attack. It's mainly soccer hooligans... [they] attack Serbs and other football teams. (Interview with an 18-year-old, male Dinamo fan in Metković, September 2017) 
Being socialized at a young age to identify with the culture of the team, this youth is cognizant of the geographical implications of his identification. Dalmatia, or the southern coastal region of Croatia, represents a hotbed region outside the confines of his own team's territory, which encompasses most of central and northern Croatia. Due to his affiliation with Dinamo, he feels threatened by the risk of physical violence against him in certain spaces, which he believes is inextricably linked to his own identity. This exemplifies the power that club football membership has on shaping the geographies of belonging. I met with a local youth basketball coach in eastern Croatia, who described to me why he believes sporting culture has such as large grip on the politics of identity in the nation:

Croatia is a very athletic country. We only have four million people, but we are good at basketball, water polo, handball, volleyball, football—all these sports. [Because of this], sports are a way of life for us... we are very competitive. I have coached in Canada and there is no culture of competitiveness there. The kids [there] do not care to win. Here, we work very hard to be the best, so the sport becomes how we see ourselves. (Interview with a 40-year-old, male coach and Hajduk fan in Slavonski Brod, September 2017)

The historical achievements of sports in Yugoslavia have saliently carried over in importance to successor states like Croatia, where sporting outcomes continue to play a preponderant role in shaping identity. Being so collectively engaged in sports carries positive impacts on unity when a local team is successful. In my interviews, Dinamo's accomplishments in club football have propelled fans in Zagreb to identify more positively with their city, a process termed basking-in-reflected-glory, or "BIRGing," where local success drives greater feelings of team identification toward a locality (Cialdini et al. 1976). These successes serve an "ego enhancement function," allowing fans to develop feelings of pride that strengthen their personal connections to local spaces (Wann and Branscombe 1990). Stronger affiliation with a region, however, comes at the cost of a clearer distancing with others, reinforcing a bifurcation between ingroups and outgroups clearly defined by team membership. We see this dynamic play out quite commonly in Zagreb, where some locals have built up feelings of resentment toward Croats from other regions, particularly Dalmatia. At a youth hostel in Zagreb, I interviewed a college student who displayed this type of regional prejudice in how he viewed Croats from elsewhere:

I don't like hearing other accents in my city, especially from the south on days when we have games; I feel bothered hearing it. I am proud of our Stokavian accent [commonly spoken in Zagreb and the basis of Standard Croatian]. It would be like if you had a bunch of Serbians speaking Serbian here. You feel like you are being crowded out! (Interview with a 21-year-old, male Dinamo fan in Zagreb, August 2017)

This Dinamo fan implicitly associates his encounters with the Dalmatian accent with the prevalence of football fans from Hajduk, a link which has led to his own behavioral prejudice against Croats from the south. Club football is only one of many sports within the country; yet for many Dinamo fans having such a fierce rivalry with an opposing team from the south has engendered feelings of prejudice against Dalmatians in general, regardless of their interest in club football. These teams, as a result, become culturally representative of entire geographical regions of people, at least to outsiders, carrying with them numerous implications that are highly consequential. One such consequence is the fear of random violence cited by fans from other cities. Creating a psychological link between an accent and a football team only magnifies the perceived differences of regional "others," allowing the Dinamo-Hajduk derby to negatively influence the north-south dynamic within the Croatian national identity. The influence club football rivalries have on inter-regional prejudice is perhaps felt most by transplants from these 
regions. I spoke with a woman in a café, who moved from a small village in southern Croatia to her current job at a marketing firm in Zagreb:

There really is a difference between the way Dalmatians are perceived here in Zagreb. I have to prove to my boss that I am not a lazy person, because this is our stereotype. Most of the time, we only make fun of each other and that's okay... [but] on game days with Hajduk, my accent becomes a little more dangerous here. (Interview with a 32-year-old, female Hajduk fan in Zagreb August, 2017)

While a certain degree of typecasting has always been prevalent between the regions, these stereotypes have generally existed either neutrally or as good-natured banter. The violence surrounding these games, however, has more recently impacted these stereotypes in the postYugoslav era and negatively influenced how Zagrebians view Dalmatians. Croatians from the south, identifiable by their distinctive accents, are perceived as characteristic out-groups on game days, embodying the oppositional team in highly symbolic ways. For radical football fans, this may impel them to pursue displays of hostility against these perceived "enemies," fueling their inter-regional prejudices. In the club football world, these prejudices, shaped by team rivalry, often produce violent ends.

I know a guy who had Split [car] plates and he was driving to a Hajduk-Dinamo game... on the way to Zagreb, he was stopped by four cars and they took him out and beat him up in front of his son. They didn't care whether or not he was a Hajduk fan; he had Split plates and that was enough for that. People link where you are from and the team; it does not matter if you are or are not a fan in actuality. (Interview with a 25-year-old, male Dinamo fan in Gospić, October 2017)

As demonstrated in this anecdote, violence surrounding club football rivalries is not isolated to merely those who participate in the sport. Radical fans, empowered by a tribal enthusiasm on game days, often channel their energy into violence, most of which is spontaneous and impulsive. The sheer force behind the "Bad Blue Boys" collective has created an identity among fans that is synonymous with Zagrebian identity. This comes at the expense of marginalizing regional "others," many of whom are subject to the pressures of negative hostility. The intensity of this rivalry is highly visible even to non-football fans, as regional "others" are acutely aware of the risk of spontaneous violence against them on game days, regardless of their participation. While these acts of violence are still considered rare, they represent hostilities reproduced and magnified by Dinamo's rivalry, supplanting the cohesiveness of Croatia's national identity.

\section{Hajduk Split}

It is serious here. We are born, and then we are Hajduk. We are the oldest club team in the world. The games we have are something special, and you can even see all the lights from space. When we play, it looks like the end of the world... Armageddon, the entire city filled with those lights, like magic. (Interview with a 28-year-old, male Hajduk fan in Split, October 2017)

As the southern counterweight to Dinamo Zagreb's dominance in Croatian football, Hajduk Split is also regarded as one of the "Big Four" of Yugoslavian football. Founded in 1911 at the end of the Austro-Hungarian period in the eponymous city of Split, the team is among the oldest in the region, predating its counterpart by more than three decades. Hajduk's fervent fanbase, known collectively as the Torcida (crowd), owe their namesake to the feverish crowds of Brazilian fans from the 1950 FIFA World Cup. Today, Hajduk's notoriety lies in the intensity of its fanbase and its 
explicit connections to ultra-nationalism, much of which has largely overshadowed the team's own accomplishments on the pitch. Recent controversies include the chanting of "ubij Srbina" (kill Serbs) at matches, along with the team's widespread appropriation of the American Confederate flag, a co-opted emblem of the "rebellious south" that fans symbolically associate with Croatia's southern Dalmatian coast. On the outside, Hajduk resembles a private stock company more than a football team, having been transferred to public ownership since 2008. But in the eyes of the Torcida, its operations belie the cultural significance the team has had on Dalmatian identity. In a bar in the "old town" part of Split, I interviewed a local who robustly described his own identity in connection to the team:

Okay, Dinamo is just a club team that people cheer for-Hajduk is our religion. That is the difference. We were born Torcida and Hajduk is in our blood. It is a part of who we are as people. Everyone in Split likes Hajduk... [and] there is no separating that. (Interview with a 38-year-old, male Hajduk fan in Split, October 2017)

Descriptions of team membership transcending the sport itself were largely echoed to me by Hajduk fans, who often invoked a deeper, cultural connotation behind their fanaticism for their team. My own usage of the terms "team" and "fan" in these conversations was often rebuffed by radical fans, many of whom felt the terms watered down the significance of their Torcida identity. For them, Hajduk represents an ideological manifestation of southern Croatian identity-of the Dalmatian spirit. This was a recurring theme expressed to me by numerous Torcida, many viewing it as an inseparable part of their social identity.

In all of Dalmacija, Hajduk is our team... it is our territory. If I see someone wearing a Dinamo shirt, or the Dinamo colors, here in my town in the city center, I will fight him... I will probably lose my job, but I will get rid of my job if I see that person from the Dinamo team in my town.... It's not about attacking other people. It is about protecting our territory. If they wear those colors in our town, they are disrespecting us to our faces. (Interview with a 23-year-old, male Hajduk fan in Split, October 2017)

This type of radical fanaticism is not uncommon among ultra Torcida fans who, like their "Bad Blue" counterparts, number in the thousands throughout the city on game days. The impulsive nature of these confrontations demonstrates the complex meanings attached to each team's paraphernalia. Specific colors (e.g., blue for the north, white for the south) have grown to symbolize geographical regions and, to the most radical of fans, the mere presence of an outside color represents a territorial transgression. This extremism is explained, in part, by Hajduk being one of the only tangible forms of a Dalmatian regional identity, one that is distinctly separate from Croatia. The team acts as a conduit for the expression of a southern coastal identity that views itself as culturally distinct from Zagreb. Therefore, Dinamo's presence represents not simply a rival team but a central Croatian encroachment upon the identity of the south. I spoke to a Dalmatian transplant living in western Croatia, who expressed to me the symbolism behind these matches:

A lot of people in Dalmatia just really don't like Zagreb and the other way around. I think we are pretty divided as Croats... you see a lot of hatred between us in the country... between the regions. It's not just about football-it's really the way we think about each other. (Interview with a 23-year-old, male Hajduk fan in Rijeka, October 2017)

The Dinamo-Hajduk derby, in effect, symbolizes resentment between the two main regions of Croatia. Football confrontations act as a proxy for regionalist sentiments-in the same manner that international matches often mirror existing geopolitical relations between states. The politics of identity have become so deeply embedded in club football that the fanbase and the city have become inseparable. Therefore, Dinamo's consistent success in the national league, in 
the eyes of Dalmatians, has grown to symbolize the disproportionate political power Zagreb wields as Croatia's economic and cultural capital. It has called into question both wealth and power inequalities within the state, as well as the rampant corruption Dalmatians perceive in the nation's capital. Hajduk fans often express their resentment by implementing the use of boycotts in order to protest management practices (Perasović and Mustapić 2013; Tregoures 2017). Some take these grievances further by choosing to boycott the Croatian national team despite its accomplishments on the global stage. During Croatia's World Cup qualifying matches, I spoke with a Hajduk fan who went so far as to cheer for the opposing team rather than support Croatia's own national team:

We cannot support [the national team], because it's controlled by Dinamo. The owner of Dinamo is also the head coach and owner of the national football team... The Dinamo team manager is also national team manager, so they put mostly Dinamo players on the national team. It is all mafia organization at the end of the day. There is so much corruption... that team doesn't represent us at all. (Interview with a 23-year-old, male Hajduk fan in Split, October 2017)

Feelings of resentment toward a politically dominant Zagreb among Hajduk fans has surpassed the unifying effects the national team has on the south. Even with Croatia's recent FIFA World Cup performance, this fan expressed a clear sense of apathy toward the accomplishments of the national team, one which he felt disillusioned by and far removed from. Hajduk's highly visible displays of Dalmatian regionalism serve as continuous reminders to fans of their cultural and economic separation from Zagreb. This has only magnified the perceived divisions between Croats of different geographical regions. These two teams remain highly divisive forces, wielding immense power in reifying regionalist identities through their continuous reproductions of difference at these football confrontations.

\section{The Culture of "Hooliganism"}

Sometimes we use weapons-anything we can find, like broken bottles. People do not bring guns or knives because that is cheating... we don't wear gloves, we fight with our bare hands and knuckles, and if someone is hit and falls to the floor, we stop... because if they die, we will go to jail... if you use a gun on me, everyone will think you are a pussy. You have to fight with only hands. That is how to be a man. (Interview with a 21-year-old, male Dinamo fan in Tomislavgrad, September 2017)

How does the culture of sports fanaticism turn violent? We know that most fan affiliations are generally moderate, and the average spectator does not participate in direct violence (Dunning 1981). Yet there are those who turn to more intense engagements, known colloquially as "hooligans," who express their fanaticism for their team in violent ways. Violence among club football fans is not a phenomenon unique to Croatia. The notoriety of "hooliganism" has plagued many European football leagues in the last few decades, perhaps most notably in the English Premier League of the 1980s and 1990s (Perryman 2001). In both Zagreb and Split, symbols of hooligan culture are ubiquitous, characterized by graffiti tagging on both sides, meant as territorial markings as well as acts of provocation. For the radical fans I spoke to on both sides, many condoned the use of violence and even professed it to be a legitimate outlet for their expressions of identity and frustration. The ritualization of violence between these two teams is often portrayed as a modern phenomenon, though it has existed since the 1970s (Perasović and Mustapić 2013). Only in the post-Yugoslav period has this violence become more openly ritualized, having now evolved into a public spectacle, in many cases, for those who flock to the derbies to observe. In southern 
Herzegovina, I interviewed a Bosnian Croat, who described his own rootedness to Dinamo, despite living more than 400 kilometers away from Zagreb:

I love Dinamo, but when they have games in Zagreb, I cannot go because it is something like a ten hour drive to Zagreb... but if they ever play Hajduk, Split is only 45 minutes away and I drive there to defend my team and their territory. It is a psychological thing with territory in football culture. Everyone has their territory and they want to defend it, and fighting is a way of settling it. (Interview with a 22-year-old, male Dinamo fan in Tomislavgrad, September 2017)

Contested ideas of territory frame the dynamics of hostile engagements at each of these games. For radical football fans, these matches represent more than just the playing of a sport but rather a political confrontation between the values of their respective cultural regions. Geography certainly plays a role in the way hooliganism is concentrated and distributed. In Split and Zagreb, inter-club fighting and engagement is most intense, with the center of incidents radiating outward from these core zones.

The rivalry between us and Dinamo are exactly like the problem with us and Serbs. I've been to Zagreb with my ten friends. I was the smallest, and you see I am almost two meters tall, and I was keeping my head down... walking with my hands in my pocket, trying not to speak too much. Because of my accent, they know from when I speak that I am from Split. I don't like to fight, but if they come and say stuff to cause problems, then I will fight them. (Interview with a 23-year-old, male Hajduk fan in Split, October 2017)

Many hooligans actively incite inter-club violence, while others feel drawn to it under the general circumstances surrounding game activities. For both, the act of fighting itself is often described in cathartic terms, allowing them to purge the individual frustrations they carry. These emotions embody many of the sentiments shared among Croat youth, who feel veritably discontented by the lack of equitable economic opportunities within the state. These frustrations, coupled with the state's perceived political corruption, have led to a massive exodus of Croatian youth to other European Union states, a movement that has only accelerated since Croatia's ascension into the EU in 2013. For those who remain, the culture of hooliganism serves as an accessible medium for disgruntled youth to express their personal frustrations through the outlet of a powerful collective. This increase in team identification among the post-Yugoslav youth has strengthened the fierceness of hooligan rivalries. For many youths, it is the only way they feel they can be heard amidst the grim economic prospects and high unemployment rates that afflict their demographic. These worsening economic conditions have only increased the fierceness of the north-south divide in recent years. To some, it mirrors the intensity of Croat-Serb relations, a historically complex relationship that has only deteriorated since the dissolution of Yugoslavia.

\section{Power of Team Identification}

We all irritate each other so much. In Zagreb, they are so irritated by the Dalmatian accent; Dalmatians are irritated by the Slavonski accent... so even though we are all Croats, the Dinamo-Hajduk rivalry represents the different cultures even inside Croatia. (Interview with a 22-year-old male Dinamo in Tomislavgrad)

Dinamo's fanbase wields an unmistakable grip on political discourse in the state's capital. The "Bad Blue Boys" has been one of the most politically powerful groups, with their early support for Franjo Tudjman's presidential candidacy in 1990 being credited with advancing popular support for Croatia's independence movement (Bellamy 2003). Tudjman himself was known to be an avid 
fan, with the former president having financed the team through the 1990s until his death in 1999 . Political figures often utilize the team's influence during election year campaigns, and Dinamo's management is inextricably linked to federal decision-making. The 2018 indictment of the team's longtime executive director, Zdravko Mamic, on charges of corruption and bribery demonstrates this nexus between the team and its connections to public officials (BBC 2018). Despite these unscrupulous links, the team maintains a radical following that sways public opinion in Zagreb while shaping political identities in the north.

Hajduk's fanbase carries a similar strength in the city of Split, though its influence has expanded to Dalmatia in recent decades. The team was mired by poor management, financial losses, and a string of game-related upsets through the 1990s. This prompted the Torcida fanbase to seek changes to its organizational structure, a shift which dissolved the team's private holdings, turning it into a joint-stock company in 2008. The city of Split has since owned most shares on Hajduk, a move that has only strengthened the team's synonymous association with the city's inhabitants. The Torcida have become inseparable from the politics of the south, wielding a similar influence as their northern counterpart on Dalmatian identity politics, if not even greater in intensity.

Since Zagreb and Split are the two most populated cities in Croatia, urban concentration seems to play a part in the formation of regional identities. Football fans in smaller cities I visited often lamented about the absence of a successful local team to coalesce around, demonstrating an awareness among fans about the effects club teams have on regional identity-building.

[In Slavonia], we are village people and we do not have as strong of an identity as you would find in Zagreb or Dalmatia. They have bigger cities... and big teams, so Croatians from those places are like that. We have our own distinctive accent but not really our own culture... there is no big "Slavonian" identity. (Interview with a 19-year-old, male Osijek fan in Osijek, September 2017)

The lack of local representation elsewhere has also strengthened the spheres of influence both Dinamo and Hajduk have, as regional "others" outside of the north-south dynamic have also developed their own local "Bad Blue Boys" and Torcida followings. In one instance, I witnessed a BBB-Torcida clash between dozens of hooligans as far east as Vukovar, a town on the CroatianSerbian border over 300 kilometers away from Zagreb and 600 kilometers from Split. Club football culture has a high influence on cultural identity, and the two remain inseparable in the milieu of Croatian politics.

\section{Implications on Croatian National Identity}

What, then, are the impacts Dalmatian and Zagrebian regionalisms have on Croatia's national identity? What implications do these regionalisms have on nationalist discourse? We know that national and regional identities are peculiar entities. They exist, overlapping in a multitude of ways, and are oftentimes contradictory, paradoxical, and highly contingent on place and time. Identity does not always exist in a static manner; instead, it is often understood within the context of an environment and to whom one is identifying to. The presence of sub-national identities, particularly the strength behind Dalmatian regionalism, belies dominant ideas of Croat nationalism put forth by right-leaning parties, such as the Croatian Democratic Union or HDZ, which has remained the state's largest single party since the 1990s. The HDZ ruled Croatia from 1990—through its war for independence - until the 1999 death of Franjo Tudjman, its preeminent founder and the first president of Croatia. It maintained coalition power through most of the following period, having only been a part of the opposition from 2011-2016. It has since re-gained its coalition power, now led by President Grabar-Kitarovic, who has reintroduced Croat nationalist narratives into dominant political discourse (dubbed "Franjoism" by critics alluding to its parallels with Francoism). The HDZ has visibly utilized national media and print outlets as mediums for putting forth ideas of a 
Croatian national identity that is both cohesive and unified. Yet below the façade of Croat nationalism lay contested regionalisms that run counter to the claims of unity by the state government. This explains, in part, the HDZ's attempts to dissuade these burgeoning regionalisms by propagandizing images of a unified Croat national identity.

Club football teams have proven to be a challenge against the state's cultivation of nationalism. "Professional clubs have been of secondary importance for the Croatian national identity (re) construction process, so there is usually no mention of them [in historical textbooks on sports]" (Hrstić and Mustapić 2015). Thus, the central government's efforts to promote the national team have become nation-building projects aimed at subverting the divisions club football has created. Among those in Zagreb, this tactic has worked as Dinamo fans often transfer their enthusiasm to the national team in global competitions. For those in Dalmatia, however, the national team has only become increasingly synonymous with Zagreb. This perception of Zagreb's interconnectedness to the national team, both in politics and in organized crime, has damaged the national team's appeal to those in the south, largely weakening its institutional role as a cohesive source of national identity. This has fueled Dalmatian regionalism, which has only become more visible since the establishment of Croatia's independence. In the eyes of one Hajduk fan:

You have these people who profess Croatian pride, but it is only in name. We were only united fighting against Yugoslavia. After that, now what? Croatia today is too divided, and we as

Dalmatians have nothing in common with Zagreb. (Interview with a 37-year-old, male Hajduk fan in Makarska, September 2017)

Economic disparities have also magnified these differences, as the concentration of wealth and power in Croatia's capital continues to produce feelings of resentment among Dalmatians, who live along its southern coastal region. These feelings of economic resentment are reproduced in the club football engagements between Dinamo Zagreb and Hajduk Split. For the former, these games symbolize Zagreb's dominance over the state as its cultural flagbearer, economic center, and seat of political decision-making. For the latter, these games have become an outlet for the expression of Dalmatian identity, which persists despite Zagreb's asserted dominance. Both are teams that have grown to represent more than just their radical fanbases: they represent the dividedness of the Croatian nation.

While no real movement for Dalmatian autonomy has gained noticeable traction, the increase in awareness of a separate cultural identity has only grown along the southern coast. The power of the Torcida in rallying Dalmatian identity comes with their historical underdog status, both as a team less successful than their counterpart and as a peripheral region of the country's political core in Zagreb. Croatia's "Homeland War" for independence from Yugoslavia saw the bulk of the conflict occur along the Dalmatian coast, Lika, and eastern Slavonia. Zagreb was largely spared by the war, and yet in the eyes of many, it has reaped the rewards of Croatia's independence most as the political and economic capital of the state. Complaints of high taxes from the coast being siphoned off to fill the coffers of Zagreb are commonplace as are calls for decentralizing the powers of the state apparatus. This resentment toward the capital has only broadened the influence of Hajduk, a team which has become a symbolic reservoir of the interests and identity of the southern coast. The ostentatious actions of the Torcida-flares, firecrackers, and smoke bombs-thus embody many of the frustrations among Dalmatian youth, who feel politically and economically marginalized by an ostensibly wealthier and seemingly corrupt Zagreb.

\section{Conclusion}

Prior to the dissolution of Yugoslavia in the 1990s, the idea of a Croatian national identity had always been an abstract one, rooted in a historical narrative that spanned centuries of yearning for a national state (Bellamy 2003). Since its independence, Croats across the state have imagined 
different versions of what constitutes their national identity. This article does not argue that club football teams themselves are the genesis of divisions within the Croatian nation; rather, these teams are physical embodiments of underlying regional identities that have been in existence for quite some time. Their ongoing strength does, however, continue to reproduce and reaffirm regional differences; we see this in the linkage between Hajduk's outsized role as a social institution and the peculiar strength of Dalmatian regional identity, relative to other regions like Slavonia. Croatia's independence from Yugoslavia granted Croats the right to unfettered self-determinism for the first time in nearly a millennium. Yet given the complex way the Croatian nation had been divided for centuries by imperialist powers (e.g., Ottomans, Venetians, Habsburg, etc.), modern Croats today have developed very regional ideas of what constitutes their identity as a nation. As a shared struggle against the perceived encroachment of a Serb-dominated Yugoslavia, Croat nationalism was indeed a concrete force in the late 1980s through the mid-1990s. In the absence of this looming external threat today, the very notion of a Pan-Croat identity has become much more amorphous.

It is apparent that club football forces do play a preponderant role in validating and reproducing regionalisms, though this article argues that the inherent tensions surrounding these rivalries are a symptom of historical and economic differences that have not been fully mediated. While the former is a byproduct of centuries of imperialist divides, the latter has only widened, as worsening economic conditions have increased inequality and resentment between regions. This interregional prejudice, as borne out in club football culture, continues to ideologically undermine the dominant notions of a Pan-Croat identity pushed by nationalists, including the HDZ. It is not to say that regionalism and nationalism within Croatia cannot exist concurrently. These identities are not mutually exclusive and some forms of overlap certainly occurs. It does, however, beg the question of whether Croat nationalism in the post-Yugoslav landscape remains organically derived or as a politically driven fantasy meant to compensate for the reality of its internal dividedness. This is a question posited by this research that should certainly be further investigated. It is no question that nationalists can and will continue to propagate "Franjoist" narratives of a unified Croatia. Though, if these club football teams continue to wield their disproportionate regional influences, that narrative will remain contradicted by the realities of these inter-regional tensions. These internal divisions disrupt the state's ideological messages and will perpetually undermine notions of unity within Croatia's national imaginings.

Disclosure. Author has nothing to disclose.

\section{References}

Abdi, Kambiz, Mahdi Talebpour, Jami Fullerton, Mohammad Javad Ranjkesh, and Hadi Jabbari Nooghabi. 2018. “Converting Sports Diplomacy to Diplomatic Outcomes: Introducing a Sports Diplomacy Model.” International Area Studies Review 21 (4): 365-381.

Agnew, John. 1998. Geopolitics: Revisioning World Politics. London: Routledge.

Allen, Dean. 2009. "South African Cricket and British Imperialism, 1870-1910." Sport in Society 12 (4-5): 464-481.

Baker, Catherine. 2016. "Football, History, and the Nation in Southeastern Europe." Nationalities Papers 44 (6): 857-859.

BBC. 2018. “Zdravko Mamic, Croatian Football's Mr. Big, Given Jail Term.” British Broadcasting Corporation, June 6. https:// www.bbc.com/news/world-europe-44381167. (Accessed February 2, 2019.)

Bellamy, Alex. 2003. The Formation of Croatian National Identity: A Centuries-Old Dream? Manchester: Manchester University Press.

Brentin, Dario. 2013. “'A Lofty Battle for the Nation': The Social Roles of Sport in Tudjman's Croatia.” Sport in Society 16 (8): 993-1008.

Brentin, Dario. 2014. “Now You See Who Is a Friend and Who Is an Enemy.' Sport as an Ethnopolitical Identity Tool in Postsocialist Croatia." Südosteuropa 62 (2): 187-207.

Brentin, Dario. 2016. "Ready for the Homeland? Ritual, Remembrance, and Political Extremism in Croatian Football." Nationalities Papers 44 (6): 1-17.

Casaqui, Vander. 2015. "The Players of the Brazilian Football Team as a Model of Culture: Life Stories Mediated by Television News.” In Sports and nationalism in Latin/o America, edited by Héctor Fernández L’Hoeste, Robert McKee Irwin, and Juan Poblete, 109-124. Basingstoke: Palgrave MacMillan. 
Cashmore, Ellis. 2000. Sports Culture: An A-Z guide. London: Routledge.

Cialdini, Robert, Richard Borden, Avril Thorne, Marcus Randall, Stephen Freeman, and Lloyd Renolds Sloan. 1976. "Basking in Reflected Glory: Three (Football) Field Studies.” Journal of Personality and Social Psychology 34 (1): 366-375.

Devan, Pamela. 2012. "Cricket and the Global Indian Identity." Sport in Society 15 (10): 1413-1425.

Dunning, Eric. 1981. "Social Bonding and the Socio-Genesis of Violence." In The Sociological Study of Sport: Configurational and Interpretive Studies, edited by Alan Tomlinson, 1-35. Brighton: Brighton Polytechnic.

Fanuko, Nenad, and Furio Nadin. 1991. Zagrebački nogometni navijači: grupni portret s BBB u središtu [Football Supporters in Zagreb: Group Portrait with BBB in Focus]. Zagreb: Institute for Social Research in Zagreb.

FIFA. 2018. "More than Half the World Watched Record-Breaking 2018 World Cup." Fédération Internationale de Football Association. December 21. https://www.fifa.com/worldcup/news/more-than-half-the-world-watched-record-breaking2018-world-cup. (Accessed February 2, 2019.)

Hay, Roy. 1998. "Croatia: Community, Conflict and Culture: The Role of Soccer Clubs in Migrant Identity." Immigrants and Minorities 17 (1): 49-66.

Hong, Eunah. 2011. "Elite Sport and Nation-Building in South Korea: South Korea as the Dark Horse in Global Elite Sport." International Journal of the History of Sport 28 (1): 977-989.

Houlihan, Barrie, and Jinming Zheng. 2015. “Small States: Sport and Politics at the Margin.” International Journal of Sport Policy and Politics 7 (3): 329-344.

Hrstić, Ivan, and Marko Mustapić. 2015. "Sport and Politics in Croatia: Athletes as National Icons in History Textbooks.” Other Modernities 14 (11): 148-165.

Hughson, John, and Fiona Skillen. 2014. Football in Southeastern Europe: From Ethnic Homogenization to Reconciliation. London: Routledge.

Jackson, Steven, and Stephen Haigh. 2008. "Between and Beyond Politics: Sport and Foreign Policy in a Globalizing World." Sport in Society 11 (4): 349-358.

Kobierecki, Michał. 2017a. "Sports Performance and Shaping International Image of a China: Towards Beijing 2008 Olympic Games." Polish Political Science Yearbook 46 (1): 138-150.

Kobierecki, Michał. 2017b. "Sports diplomacy of Norway." International Studies: Interdisciplinary Political and Cultural Journal 20 (1): 131-146.

Kolstø, Pål. 2006. "National Symbols as Signs of Unity and Division.” Ethnic and Racial Studies 29 (4): 676-701.

Lalić, Dražen, and Shay Wood. 2014. "Football Hooliganism in Croatia: A Historical and Sociological Analysis." Südosteuropa 62 (2): 145-169.

L'Etang, Jacquie. 2013. Sports Public Relations. Los Angeles: Sage.

Majumdar, Boria, and Kausik Bandyopadhyay. 2005. "Regionalism and Club Domination: Growth of Rival Centres of Football Excellence." Soccer and Society 6 (2): 227-256.

Mangan, J. A, ed. 1996. Tribal Identities: Nationalism, Europe, Sport. London: Frank Cass.

Mangan, J. A., Hyun-Duck Kim, Angelita Cruz, and Gi-Heun Kang. 2013. "Rivalries: China, Japan and South Korea - Memory, Modernity, Politics, Geopolitics - and Sport.” The International Journal of the History of Sport 30 (10): 1130-1152.

Melnick, Merrill, and Daniel Wann. 2004. "Sport Fan Influences, Interest, and Behaviors among Norwegian University Students.” International Sports Journal 8 (1): 1-13.

Mills, Richard. 2009. “'It All Ended in an Unsporting Way’: Serbian Football and the Disintegration of Yugoslavia, 1989-2006.” International Journal of the History of Sport 26 (9): 1187-1217.

Mills, Richard. 2018. The Politics of Football in Yugoslavia: Sport, Nationalism and the State. London: I.B. Tauris.

Murray, Stuart. 2012. “The Two Halves of Sports-Diplomacy.” Diplomacy and Statecraft 23 (3): 576-592.

Murray, Stuart, and Geoffrey Pigman. 2014. "Mapping the Relationship between International Sport and Diplomacy." Sport in Society 17 (9): 1098-1118.

Nye, Joseph. 2009. Soft Power: The Means to Success in World Politics. New York: Public Affairs.

Pavlaković, Vjeran. 2014. "Fulfilling the Thousand-Year-Old Dream: Strategies of Symbolic Nation-Building in Croatia." In Strategies for Symbolic Nation-Building in South East Europe, edited by Pål Kolstø, 19-50. Farnham: Ashgate.

Perasović, Benjamin, and Marko Mustapić. 2013. "Football Supporters in the Context of Croatian Sociology: Research Perspectives 20 Years After.” Kinesiology 45 (2): 262-275.

Perasović, Benjamin, and Marko Mustapić. 2018. “Carnival Supporters, Hooligans, and the 'Against Modern Football' Movement: Life within the Ultras Subcultures in the Croatian Context." Sport in Society 21 (6): 960-976.

Perica, Vjekoslav. 2001. "United They Stood, Divided They Fell: Nationalism and the Yugoslav School of Basketball, 19682000." Nationalities Papers 29 (2): 267-291.

Perryman, Mark. 2001. Hooligan Wars: Causes and Effects of Football Violence. Edinburgh: Mainstream Publishing.

Popovic, Stevo, and Dusko Bjelica. 2014. "Do Significant Achievements of National Football Team Can Strengthen National Identity in Montenegro?" Montenegrin Journal of Sports Science and Medicine 3 (1): 31-33.

Rowe, David. 2011. Global Media Sport, Flows, Forms and Futures. London: Bloomsbury.

Saxena, Anurag. 2011. The Sociology of Sport and Physical Education. New Delhi: Sports Publications.

Seib, Philip. 2009. Toward a New Public Diplomacy: Redirecting U.S. Foreign Policy. Berlin: Springer. 
Sindbaek, Tea. 2013. “'A Croatian Champion with a Croatian Name’: National Identity and Uses of History in Croatian Football Culture - the Case of Dinamo Zagreb." Sport in Society 16 (8): 1009-1024.

Smits, Jeroen. 2010. "Ethnic Intermarriage and Social Cohesion: What Can We Learn from Yugoslavia?" Social Indicators Research 96 (3): 417-432.

Snyder, Scott. 2018. South Korea at the Crossroads: Autonomy and Alliance in an Era of Rival Powers. New York: Columbia University Press.

Toledo, Renata, and Maria Tarcisa Silva Bega. 2015. "Nationalism and Public Policies of Sports in Brazil." In Sports and Nationalism in Latin/o America, edited by Héctor Fernández L'Hoeste, Robert McKee Irwin, and Juan Poblete, 125-139. Basingstoke: Palgrave MacMillan.

Topić, Mojca, and Jay Coakley. 2010. "Complicating the Relationship between Sport and National Identity: The Case of PostSocialist Slovenia.” Sociology of Sport Journal 27 (4): 371-389.

Tosa, Masaki. 2015. "Sport Nationalism in South Korea: An Ethnographic Study.” Sage Open 5 (4): 1-13.

Tregoures, Loïc, and Goran Šantek. 2017. "A Comparison of Two Fan Initiatives in Croatia: Zajedno za Dinamo (Together for Dinamo) and Naš Hajduk (Our Hajduk).” Soccer and Society 19 (3): 453-464.

Tregoures, Loïc. 2017. "Beyond the Pattern: Corruption, Hooligans, and Football Governance in Croatia." In Football and Supporter Activism in Europe: Whose Game Is It?, edited by Borja García and Jinming Zheng, 165-186. London: Palgrave Macmillan.

Wann, Daniel, and Nyla Branscombe. 1990. "Die-Hard and Fair-Weather fans: Effects of Identification on BIRGing and CORFing tendencies." Journal of Sport and Social Issues 14 (2): 103-117.

Wann, Daniel, Christi Ensor, and Jaye Bilyeu. 2001. "Intrinsic and Extrinsic Motives for Originally Following a Sport Team and Team Identification.” Percept Mot Skills 93 (2): 451-454.

Won, Hyung-Joong, and Eunah Hong. 2015. "The Development of Sport Policy and Management in South Korea." International Journal of Sport Policy and Politics 7 (1): 141-152.

Cite this article: Tsai, D. Y. 2021. "A Tale of Two Croatias": How Club Football (Soccer) Teams Produce Radical Regional Divides in Croatia’s National Identity. Nationalities Papers 49: 126-141, doi:10.1017/nps.2019.122 